\title{
REFLECTION
}

\section{The Phoenix: A 20-Year Patient-Doctor Journey}

Rutb Kannai, $M D^{1}$

Dana Salem

Aya Rice (Alon), $M A^{2}$

'Department of Family Medicine, Ben-Gurion University of the Negev, Beer Sheba, Israel

${ }^{2}$ Department of Counseling and Human Development, University of Haifa, Haifa, Israel
Conflicts of interest: authors report none.

\section{CORRESPONDING AUTHOR}

Ruth Kannai, MD

6B Apt 2 Reuven Street

Bet Shemesh Israel 99544

rkannai@gmail.com

\begin{abstract}
In a previous story ("On Blindness and Blind Spots")' I sought to understand the psychological causes of a long-time patient's myriad of seemingly inexplicable symptoms. Since then, I learned more of her story, which helped me understand my patient with a new perspective.
\end{abstract}

Dana shared with me, and now with the readers, short poetic pieces she has written to describe her traumatic experiences as a child-and the efforts she makes as a grown woman to heal, like the phoenix rises from its ashes. The value of belief in one's patient, alongside patience and the opportunity to build a trusting relationship over many years-as the truth has a pace of its own-are underscored.

Ann Fam Med 2020;18:80-82. https://doi.org/10.1370/afm.2486.

$\mathrm{T}$ he phoenix - the legendary firebird in Greek mythology as well as in the folk stories of other cultures-dies in a show of flame and combustion, only to rise again from its own ashes. It has become a symbol of resurrection and in some versions its tears can heal. In western culture, the term "phoenix" may be used to describe people who rise after adversity.

Dearest Dana,

You are a phoenix. Many times I have written about you. It began with letters to colleagues and medical advisors, in the acceptable disconnected medical jargon: age...marital status....complains of the following symptoms...test results indicate...diagnosis...

As I browse through your file I am disturbed by the unemotional language, speaking of you in third person, as a human object with a myriad of unexplained symptoms. Afterwards, I spoke about you (changing all identifying features) in my Balint group for family physicians, where I could share my concerns and frustrations regarding your care in a safe, empathic, and nonjudgmental environment. I shared that your complaints at age 15,20,30, and 35 were atypical of a young woman your age. I told of how you wouldn't agree to psychological intervention as an adjunct to the medical care for the severe physical symptoms you suffered from since we'd first met two decades ago. I told how you evoked empathy and respect despite the barrage of incurable symptoms.

At a certain point you were diagnosed with fibromyalgia, characterized by extensive pain and sleep and mood disorders. Its cause is unknown and some doctors find it a baffling and frustrating illness to address. Some may belittle it or even discount it completely.

I firmly believed in your desire to heal: for your loved ones, your children, and yourself. I denied any suspicion of secondary gain to receive monetary compensation or attention. You always seemed to have something or someone to live and function for, even during times of complete collapse.

As I cared for you, I learned about the many lessons you endured: your father's death while you were a teenager and your mother's suffering from a complex mixture of physical and emotional problems. You came from a 
poor family that always maintained its self-respect. You married your first sweetheart, yet he too died a tragic untimely death, leaving you with a year-old infant. You had many good reasons to be depressed. I assumed that, despite all that I knew, it was still only the tip of the iceberg of your pain. As an experienced physician, I thought perhaps time would eventually unravel the many layers beneath the surface of your story. One of the benefits of caring for patients for what is now over two decades, is that a more comprehensive understanding of a patient's symptoms emerges only after many years. Such continuity of care also enables a deep bond of trust to develop between patient and doctor, which also helps open the door to deeper sharing, as indeed transpired between us.

As part of my efforts to understand the inexplicable peripheral blindness that plagued you for the last decade, I wrote a story in which I related to the blindness as a metaphor, a way you unconsciously chose to avoid looking to the sides, maintaining a steadfast gaze into the future'. I thought the past and present were too painful, hence, you focused on the future. I failed to relate to the blindness itself-all that you wish to avoid for it is too horrible. In short, I wrote about the small flashlight you lit under the blanket and evaded, together with you, the giant monster in the room.

The story lay hidden in my desk for a decade. I didn't show it to others and never told you I wrote it. I was embarrassed at my own clumsy efforts to piece together the puzzle of your life and thought I was mistaken in my interpretation. I wrote it for my own purposes: to relieve some of the heartache in carrying your story and to attempt to create a cohesive narrative with a beginning, middle, and end. Writing your story served my own need for meaning-for you and for my professional life.

Two years ago I received terrible news: a man who was under my medical care was exposed as a serial pedophile. He had raped many young girls, mostly in his family, for years, in one of the villages in which I work. After the first courageous woman spoke out, additional women also began to testify, to the investigators, the court, and the media, about the cheerful uncle who had destroyed their bodies and souls. I was shocked at the news: as a doctor, as a mother, and as a human. I wondered if there was any way someone could have saved those young girls - their mothers, perhaps an older sister? The secret remained hidden for over 20 years, and nobody guessed-not the family, teachers, social workers, doctors, or nurses.

Later I learned that you too were one of his victims. You spoke out in court, and in my office. Despite the damage he inflicted upon you, you survived. You left home for boarding school, and regained confidence in love and humanity, marrying a man you loved and bringing forth new life. You managed all of this despite severe and persistent anxiety. Yet your body refused to remain silent, expressing the pain you never uttered. The conviction and incarceration of the rapist did not bring you any relief. Your body violently reacted to the horrible secret it contained: back pain and arthritis, vertigo, weight gain, metabolic syndrome...

At least now we could openly speak of the connection between your symptoms and your traumatic past. Finally, I could stop imagining and inventing your story; I could finally hear you, Dana. I shared with you the story I wrote about you and my attempts to understand you. You surprised me by revealing that you too write little "notes" — beautiful lyrical pieces, some of which you shared with me that very day. And, in your typical heroic manner, agreed to share some of your writing.

\author{
The House on the Hill \\ The bouse on the bill \\ where it all began... \\ where it all ended... \\ childbood, innocence, the piercing cry \\ the sadness, the silence, the atrocious pain \\ the almost silent scream \\ that no one beard. \\ Just one more moment, she convinces berself \\ and closes ber eyes \\ swallows ber saliva \\ and with it the pain that racks ber body \\ and refuses to let go. \\ One more moment she promises berself \\ and then you can go somewhere safe \\ to the bouse and room that \\ bears no memory of \\ what bappened. \\ Over time the young girl grew \\ and became a woman and \\ every time she passes by \\ she looks \\ and never for a moment \\ can she forget the bours... \\ the days... the months and the years... \\ there in the bouse on the bill. . \\ the familiar bouse.
}


And she smiles,

trying all the time

to be the best she can

and to continue with ber life. .

to shed all the layers of memories

that prevent ber from

moving forward and forgetting...

everything that remains etched

on ber tiny and tortured soul

everything that bappened

in that bouse on the bill,

in that familiar bouse.

And the light is still on there

like it was years ago.

and there is life inside

and she stands there in the darkness

and glances backwards with a bitter smile

trying to not remember.

She wants to move onwards

towards bappiness

but at every stage she stops

and looks backwards...

and silently questions

what would have happened

bad she been an ordinary child.
She struggles as a tear flows down,

she stands upright and sadly smiles...

I shall overcome, she promises berself

boping she will never remember

or perbaps will forget just a little

the bouse on the bill...

the familiar bouse.

\section{Am a Woman}

I am a woman!

Look at me please...

sometimes soft, sometimes tough

I am a woman.

Sometimes asking or demanding,

teeth chattering.

I am a woman.

I am botb open and bidden,

vulnerable and veiled,

a lioness and weak,

please look at me.

I am a wife and a mother

and if you look for a moment

within

you will see me

whispering in my softness,

longing and asking.
I stand brazenly without shame.

Look at me...

I am a woman.

On Her Birthday

On ber birthday

the trees will dance

in the sun's rays,

with the leaves

that now adorn the earth

after the cold winter.

In the river of ber childhood

many memories remain

choked

in a flood

of sadness.

She always preferred silence...

from which she spun

one

dress

after

anotber

with

a needle

and

tbread.
I was and remain mesmerized by your writing: about the home in which you were unprotected, about how you were abused, and about how you still knew how to give and receive love and even love yourself. Your words are as clear as your gaze, gentle and powerful. They bear witness to how you raised yourself like the phoenix from your own ashes. Through our correspondence our bond deepened. I shared my amazement at your strengths and talents; you shared your inner world. "You are one of the pillars of my success," you wrote me at one point.

My dear Dana,

It has taken nearly two decades to reveal your full story, as the truth indeed has its own pace. Thank you for trusting me. Finally, we can now address both your body and your soul. I have also discovered that despite the many differences between us-in age, profession, background, culture and life events - we are both strong women who believe in humankind and share a passion for a simple and healthy life. We are both writers-for me it is a means to touch and be touched by the world; for you it is a way to dress your wounds with the softness of language. We both write to heal something within us and within those we love. A bond of sisterhood unites us.

To read or post commentaries in response to this article, see it online at http://www.AnnFamMed.org/content/18/1/80.

Submitted April 21, 2019; submitted, revised, June 24, 2019; accepted July 17, 2019.

Key words: physician narrative; patient narrative; doctor-patient relationship; chronic pain syndrome; sexual abuse

\section{References}

1. Kannai R, Alon A. On blindness and blind spots. Ann Fam Med. 2018;16(4):364-366. 